\title{
Light hydrocarbons in volcanic gases from the Japanese island arc
}

\author{
YASUHIRO KIYOSU* and NORIKO ASADA \\ Department of Earth and Planetary Sciences, Nagoya University, Chikusa, Nagoya 464, Japan
}

(Received November 28, 1994; Accepted May 1, 1995)

\begin{abstract}
Light hydrocarbon contents were determined for volcanic and geothermal gases from the Japanese island arc volcanoes. $\mathrm{C}_{1}-\mathrm{C}_{4}$ alkanes and $\mathrm{C}_{2}$ alkene were detected, independent of fumarolic and downhole temperature. On the basis of the abundance ratios of alkanes and alkene relative to methane, the volcanic hydrocarbons are classified mainly into the fumarolic type of inorganic origin and the volcanic geothermal type of thermogenic origin.

Thermodynamic calculations are made for the reactions of inorganic hydrocarbons under redox condition governed by a variety of mineral buffer systems. The results indicate that the amounts of alkanes and alkene depend essentially on the oxygen fugacity rather than temperature or other factors such as $f_{\mathrm{H}_{2} \mathrm{O}}$ and $f_{\mathrm{CO}_{2}}$. The concentrations of volcanic light hydrocarbons are probably controlled by redox conditions during the discharge process as well as equilibrium with magma.
\end{abstract}

\section{INTRODUCTION}

Many geochemical studies on volcanic gases have been performed to determine the behavior and origin of volatile discharges such as water, carbon dioxide and sulfur compounds. For example, the magma gas components have been discussed in terms of their thermodynamic equilibrium (e.g., Ellis, 1959; Matsuo, 1960; Gerlach and Nordlie, 1975). Furthermore, the isotopic studies of steam condensates from andesitic volcanoes suggest that the water in these volcanic gases is a mixtures of magmatic and meteoric waters (Mizutani, 1978; Viglino et al., 1985; Mizutani et al., 1986; Taran, 1990). However, the origin of carbon and sulfur compounds found in volcanic gases has not yet been made clear.

Except for $\mathrm{CH}_{4}$, light hydrocarbons are minor components of volcanic gases and have rarely been investigated. Until recently, a few studies on volcanic light hydrocarbons have been reported (Stoiber et al., 1971; Markhim et al., 1977; Nehring and Truesdell, 1978; Giggenbach et al.,
1990). The results indicate that alkanes and alkenes were detected as volcanic hydrocarbons and are probably derived from the thermal decomposition of organic matter in the basement sedimentary rocks which surround the volcanoes. However, it is poorly known whether these light hydrocarbons are also of inorganic or thermogenic origin.

In the present study, light hydrocarbons found in volcanic gases from dacitic and andesitic volcanoes in the Japanese islands are analyzed and their origin and evolution are discussed.

\section{EXPERIMENTAL}

\section{Sampling}

Fumarolic and geothermal well gas samples were collected from some volcanic areas as shown in Fig. 1. More detailed information on the geology and geochemistry of these areas was summarized by Mizutani (1978), Mizutani et al. (1986), Kiyosu (1983, 1986), Kiyosu and Yoshida (1988) and Asada (1993). The sampling method used was a modification of that discussed by Ozawa (1966).

*Present address: Department of Environmental Biology and Chemistry, Toyama University, Toyama 930, Japan 


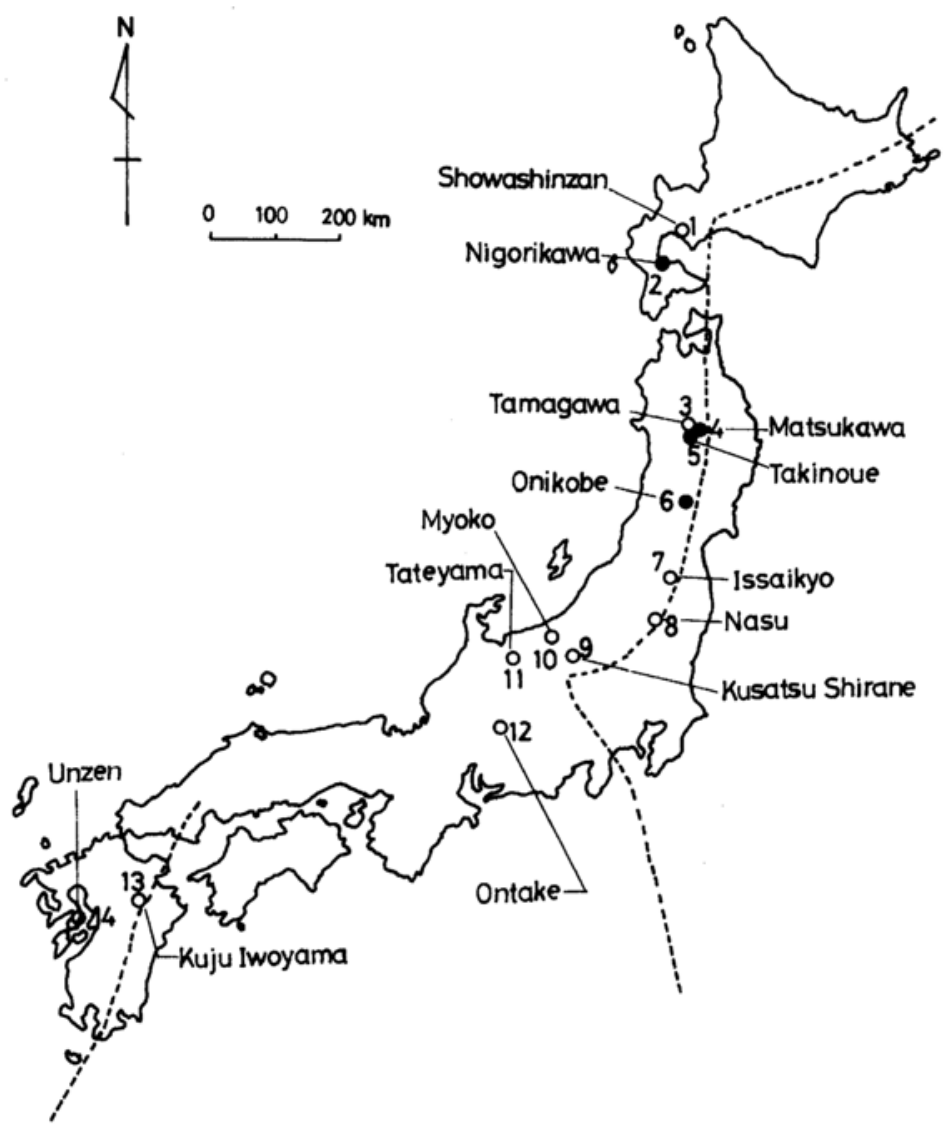

Fig. 1. Locations of volcanoes and geothermal systems, the Japanese island arc, from which gas samples were collected. Open and closed circles represent volcanoes and geothermal systems, respectively.

Gas samples were absorbed in a water-cooled 6 $\mathrm{N} \mathrm{KOH}$ solution. The dissolved $\mathrm{H}_{2} \mathrm{~S}$ was immediately fixed as CdS in order to prevent oxidation over short time periods (Kiyosu, 1983). The fumarolic temperature at the time of the gas collection was determined with the use of a thermocouple and/or a mercury thermometer.

\section{Analytical procedures}

The analytical method of water, carbon dioxide, sulfur compounds $\left(\mathrm{SO}_{2}, \mathrm{H}_{2} \mathrm{~S}\right)$, and chloride absorbed into $\mathrm{KOH}$, has been reported in detail elsewhere (Mizutani, 1978; Viglino et al., 1985; Kiyosu, 1983). The alkali residual gases such as $\mathrm{H}_{2}, \mathrm{~N}_{2}, \mathrm{O}_{2}$ and $\mathrm{CH}_{4}$ were analyzed by gas chromatography with a thermal conductivity detector (Kiyosu, 1983). On the basis of $\mathrm{O}_{2}$ contents, a correction was made for air contamination in the gas samples. The light hydrocarbons were measured by gas chromatography on a Unibead $1 \mathrm{~S}$ column having an argon carrier with a flame ionization detector. The margin $(1 \sigma)$ of error in the determination of the light hydrocarbons was $\pm 2 \%$, except for methane $( \pm 1 \%)$.

\section{RESULTS AND DISCUSSION}

Chemistry of volcanic gases in Japanese volcanoes

Figure 2a shows the relative contents in terms of $\mathrm{CO}_{2}, \mathrm{SO}_{2}+\mathrm{H}_{2} \mathrm{~S}$ and $\mathrm{HCl}$ from volcanic gases in the Japanese island arc. The water vapour contents were always $>90$ vol. $\%$. The gases can be classified into three types: high temperature fumarolic gases $\left(\geq 200^{\circ} \mathrm{C}\right)$ containing $\mathrm{HCl}$ (Matsuo, 


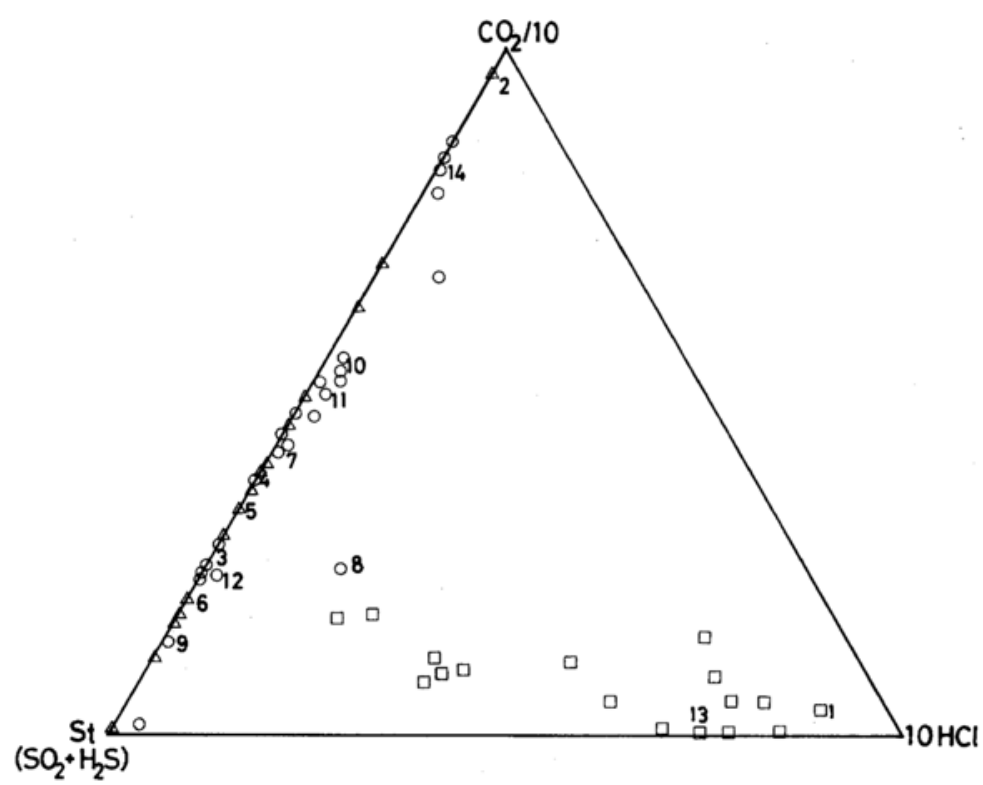

a

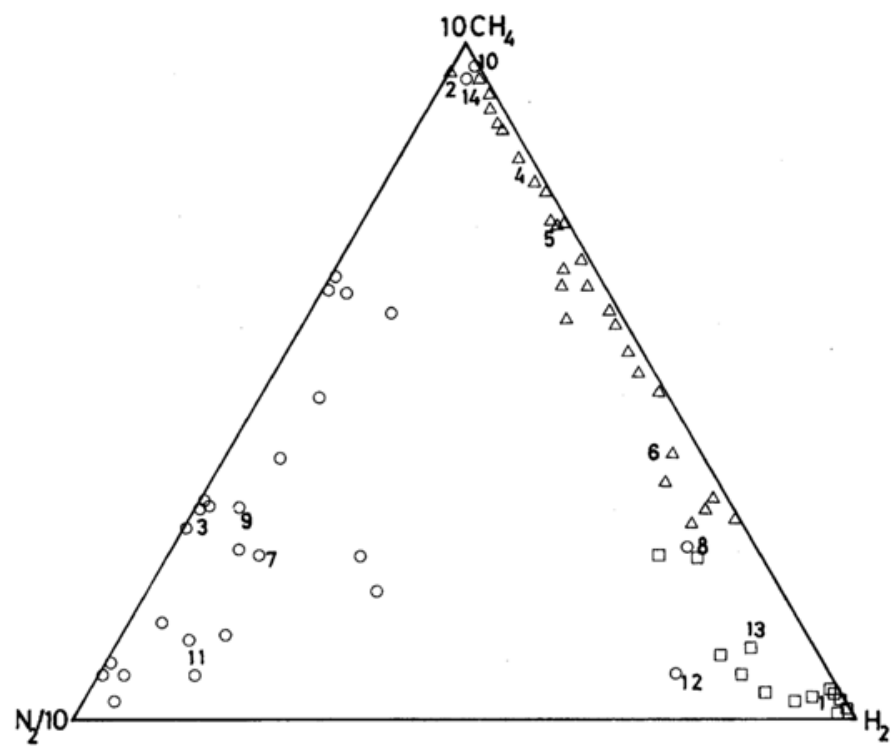

b

Fig. 2. a) Relative $\mathrm{CO}_{2}, \mathrm{SO}_{2}+\mathrm{H}_{2} \mathrm{~S}$ and $\mathrm{HCl}$ contents of fumarolic and geothermal gases. b) Relative $\mathrm{H}_{2}, \mathrm{~N}_{2}$ and $\mathrm{CH}_{4}$ contents of fumarolic and geothermal gases. 1: Showashinzan (Matsuo, 1961; Mizutani, 1978), 2: Nigorikawa (Asada, 1993), 3: Tamagawa (Kiyosu, 1983), 4: Matsukawa (Kiyosu, 1983), 5: Takinoue (Kiyosu and Yoshida, 1988), 6: Onikobe (Kiyosu, 1986), 7: Issaikyo (Kiyosu, 1983), 8: Nasu (Kiyosu, 1983), 9: Kusatsu Shirane (Asada, 1993), 10: Myoko (Asada, 1991), 11: Tateyama (Asada, 1991, 1993), 12: Ontake (Asada, 1993), 13: KujuIwoyama (Mizutani et al., 1986), and 14: Unzen (Asada, 1993). Squares, circles and triangles indicate high temperature fumarolic gases: 1, Usu (Matsuo et al., 1982), 13, Satsuma-Iwojima (Matsuo et al., 1975), low temperature fumarolic gases: 3, 7-12, 14, and geothermal gases: 2, 4, 5, respectively. 
Table 1. Distribution of light hydrocarbons, normalised to methane, in volcanic gases from the Japanese island arc

\begin{tabular}{|c|c|c|c|c|c|c|c|}
\hline \multicolumn{2}{|c|}{ Locality } & \multirow{2}{*}{$\begin{array}{c}\begin{array}{c}\text { Temp. } \\
{ }^{\circ} \mathrm{C}\end{array} \\
637\end{array}$} & \multirow{2}{*}{$\begin{array}{r}\mathrm{C}_{2} \mathrm{H}_{6} \\
5.76\end{array}$} & \multirow{2}{*}{$\begin{array}{c}\mathrm{C}_{3} \mathrm{H}_{8} \\
1.65\end{array}$} & \multirow{2}{*}{$\begin{array}{c}\begin{array}{c}i-\mathrm{C}_{4} \mathrm{H}_{10} \\
\mathrm{~m} \mathrm{~mol} / \mathrm{mol}\end{array} \\
4.55\end{array}$} & \multirow{2}{*}{$\begin{array}{r}n-\mathrm{C}_{4} \mathrm{H}_{10} \\
0.539\end{array}$} & \multirow{2}{*}{$\begin{array}{l}\mathrm{C}_{2} \mathrm{H}_{4} \\
15.0\end{array}$} \\
\hline Showashinza & & & & & & & \\
\hline & & 617 & 1.10 & 3.26 & 4.49 & 2.22 & 39.0 \\
\hline Kuju Iwoyam & & 350 & 0.60 & 0.24 & 0.10 & 0.137 & 0.67 \\
\hline Tamagawa & & 101 & 1.75 & 0.59 & 1.31 & 6.11 & 2.24 \\
\hline Issaikyo & & 94 & 10.37 & 1.43 & 2.97 & 0.937 & 5.37 \\
\hline \multirow[t]{7}{*}{ Nasu } & $0-3$ & 102 & 1.10 & 0.078 & 0.043 & 0.083 & 0.43 \\
\hline & $0-3$ & 101 & 1.65 & 0.111 & 0.022 & 0.035 & 0.38 \\
\hline & U-1 & 95 & 1.75 & 0.135 & 0.017 & 0.052 & 0.47 \\
\hline & M-1 & 171 & 1.68 & 0.128 & 0.090 & 0.079 & 1.87 \\
\hline & M-6 & 140 & 1.60 & 0.185 & 0.015 & 0.096 & 0.95 \\
\hline & UW-1 & 96 & 1.49 & 0.139 & 0.052 & 0.063 & 0.52 \\
\hline & $\mathrm{T}-3$ & 112 & 1.39 & 0.088 & 0.038 & 0.042 & 0.65 \\
\hline \multirow{5}{*}{ Kusatsu } & Kita 1 & 102 & 15.4 & 4.71 & 1.24 & 1.20 & 0.45 \\
\hline & Kita 2 & 100 & 2.03 & 0.47 & - & 0.51 & - \\
\hline & Kita 3 & 101 & 3.10 & 2.63 & 1.45 & 1.93 & 2.08 \\
\hline & Sessyou 1 & 95 & 0.41 & 0.48 & 0.11 & 0.10 & 0.14 \\
\hline & Sessyou 2 & 94 & 0.58 & 0.05 & 0.01 & 0.02 & 0.025 \\
\hline \multirow{2}{*}{ Ontake } & OT-1 & 117 & 2.60 & 0.306 & 0.054 & 0.074 & 0.10 \\
\hline & OT-2 & 115 & 2.47 & 0.274 & 0.054 & 0.101 & 0.11 \\
\hline \multirow[t]{3}{*}{ Myoko } & A-1 & 92 & 13.5 & 3.06 & 0.394 & 0.516 & 0.001 \\
\hline & A-2 & 94 & 14.6 & 3.74 & 0.484 & 0.590 & 0.002 \\
\hline & A-3 & 116 & 15.0 & 3.35 & 0.403 & 0.451 & 0.0002 \\
\hline \multirow[t]{9}{*}{ Tateyama } & A-1 & 104 & 0.73 & 0.37 & 0.335 & 0.230 & 2.13 \\
\hline & A-2 & 105 & 1.10 & 0.32 & 0.335 & 0.236 & 1.86 \\
\hline & B-1 & 109 & 0.82 & 0.33 & 0.046 & 0.425 & 1.18 \\
\hline & B-2 & 93 & 0.85 & 0.33 & 0.199 & 0.132 & 0.52 \\
\hline & 231 & 110 & 0.64 & 0.03 & 0.033 & 0.033 & 0.11 \\
\hline & 241 & 103 & 0.73 & 0.03 & 0.053 & 0.053 & 0.17 \\
\hline & $\mathrm{KAJ}$ & 102 & 0.87 & 0.24 & 0.027 & 0.082 & 0.014 \\
\hline & DAG & 107 & 2.06 & 0.60 & 0.112 & 0.196 & 0.037 \\
\hline & DAY & 108 & 1.40 & 0.353 & 0.136 & 0.203 & 0.109 \\
\hline \multirow[t]{7}{*}{ Unzen } & KAR & 26 & 5.97 & 0.70 & 0.096 & 0.075 & 0 \\
\hline & K02 & 73 & 7.12 & 1.34 & 0.303 & 0.284 & 0 \\
\hline & K01 & 98 & 5.89 & 1.05 & 0.229 & 0.154 & 0 \\
\hline & SEID & 102 & 5.77 & 1.08 & 0.233 & 0.189 & 0 \\
\hline & DAI & 94 & 6.76 & 1.07 & 0.222 & 0.124 & 0 \\
\hline & HAT & 77 & 11.5 & 1.08 & 0.224 & 0.146 & 0 \\
\hline & SIMA & 25 & 0.43 & 0.713 & 1.092 & 0.060 & 0.083 \\
\hline Nigorikawa & & $250^{*}$ & 39.1 & 14.7 & 1.90 & 0.304 & 0.332 \\
\hline \multirow[t]{4}{*}{ Matsukawa } & M-2 & $240^{*}$ & 7.27 & 0.40 & 0.030 & 0.016 & 0.211 \\
\hline & M-3 & $240^{*}$ & 2.01 & 0.19 & 0.050 & 0.218 & - \\
\hline & M-5 & $220^{*}$ & 7.22 & 0.47 & 0.009 & 0.055 & - \\
\hline & M-9 & $230^{*}$ & 4.26 & 0.19 & 0.029 & 0.062 & 0.172 \\
\hline \multirow[t]{2}{*}{ Takinoue } & A & 98 & 43.7 & 11.9 & 0.781 & 3.13 & 1.88 \\
\hline & B & 97 & 10.4 & 1.92 & 0.090 & 0.210 & 1.37 \\
\hline \multirow[t]{2}{*}{ Onikobe } & A & 99 & 10.1 & 0.51 & 0.541 & 0.118 & 10.2 \\
\hline & B & $240^{*}$ & 12.8 & 5.61 & 2.63 & 1.79 & 9.95 \\
\hline
\end{tabular}

$\mathrm{CH}_{4}=1 \mathrm{~mol}$.

-: not measured.

*downhole temperature. 
1961; Matsuo et al., 1975, 1982; Mizutani, 1978; Mizutani et al., 1986), low-temperature fumarolic gases containing some $\mathrm{HCl}$ (Kiyosu, 1983; Asada, 1991) and geothermal gases containing no $\mathrm{HCl}$ (Kiyosu, 1983, 1986; Kiyosu and Yoshida, 1988). Alkanes such as methane are present in volcanic geothermal gases being predominantly composed of carbon dioxide. On the other hand, on the basis of relative $\mathrm{H}_{2}, \mathrm{CH}_{4}$ and $\mathrm{N}_{2}$ contents, the hightemperature and low-temperature fumarolic gases and volcanic geothermal gases may be classified as $\mathrm{H}_{2}, \mathrm{~N}_{2}$ and $\mathrm{CH}_{4}$ rich, respectively (Fig. 2b). However, the Ontake and Nasu low-temperature fumarolic gases and the Onikobe volcanic geothermal gases have high $\mathrm{H}_{2}$ contents and correspond to the high-temperature fumarolic type, the low-temperature fumarolic gases from the Myoko and Unzen volcanoes contain considerably more methane and belong to the volcanic geothermal type. Thus, in addition to temperature, volcanic gases can also be classified by their chemical composition.

\section{Light hydrocarbon in volcanic gases}

The Showashinzan and Kuju-Iwoyama $\mathrm{H}_{2}$ type fumarolic gases (high-temperature) contain $\mathrm{CH}_{4}$ ranging from 1.0 to $1.2 \times 10^{-4}$ vol.\% (Matsuo, 1957; Mizutani 1978; Mizutani et al., 1986), while $\mathrm{N}_{2}$ type fumarolic gases (low-temperature) have methane concentrations between $1.2 \times 10^{-4}$ and $6.4 \times 10^{-2}$ vol.\% (Kiyosu, 1983; Asada, 1991). The Nigorikawa, Matsukawa, Takinoue and Onikobe $\mathrm{CH}_{4}$ type geothermal gases have methane from $1.9 \times 10^{-3}$ to $6.4 \times 10^{-1}$ vol.\% (Kiyosu, 1983, 1986; Kiyosu and Yoshida, 1988; Asada, 1991). The analycal results of other hydrocarbons for gas samples taken from several locations are listed in Table 1.

Volcanic hydrocarbons might deviate considerably from the equilibrium concentrations with magma due to secondary processes such as decreasing temperature, oxidation by air or surface water and contamination of hydrocarbon gases derived from groundwater or sedimentary rocks. In order to clarify the effects of these processes, the hydrocarbon gases from fumaroles in some volcanoes were examined by Asada (1991). From the results, it was found that the hydrocarbon abundance ratios in each volcano are almost uniform independent of fumarolic temperature. This suggests that the hydrocarbon gases are not affected by processes near surface, but contain information from deep-seated areas.

Several sources including inorganic, thermogenic or biogenic origin were postulated for the origin of light hydrocarbons such as $\mathrm{CH}_{4}$ associated with volcanic hydrothermal systems. Inorganic and thermogenic gases usually contain $\mathrm{CH}_{4}$ together with other light hydrocarbons, while biogenic gas predominantly methane (Schoell, 1988; Welhan, 1988). Light hydrocarbons of the East Pacific Rise (E.P.R.) hydrothermal brine were supposed to be inorganic; they have low but similar concentrations of ethane to those of butanes and alkenes such as ethylene (Welhan and Craig, 1982). On the other hand, in the thermogenic gases from oil fields the abundance of hydrocarbons relative to $\mathrm{CH}_{4}$ decreases from ethane to higher hydrocarbon but contain almost no ethylene (Schoell, 1988).

Figure 3a shows the abundance ratios of hydrocarbons in fumarolic gases from several dacitic and andesitic volcanoes. Although the relative abundance ratios of other hydrocarbons relative to methane are variable in each area, the patterns are similar to each other, suggesting that the hydrocarbon gases are of inorganic origin (Welhan and Craig, 1982), independent of the fumarolic temperature. However, the fumarolic gases from the Myoko and Unzen volcanoes belong to the volcanic $\mathrm{CH}_{4}$ type geothermal gases. On the other hand, with the exception of ethylene, the abundance patterns in geothermal gases are similar to those of thermogenic hydrocarbons (Chung, 1976; Sakata et al., 1989), as shown in Fig. 3b. One exception are the Onikobe geothermal gases $\left(\mathrm{H}_{2}\right.$ type), which indicate an inorganic hydrocarbon pattern.

Thus, almost all of the hydrocarbons in volcanic gases of $\mathrm{H}_{2}$ and $\mathrm{N}_{2}$ types have the pattern of inorganic origin, whereas the methane rich fumarolic and geothermal gases are of thermogenic 

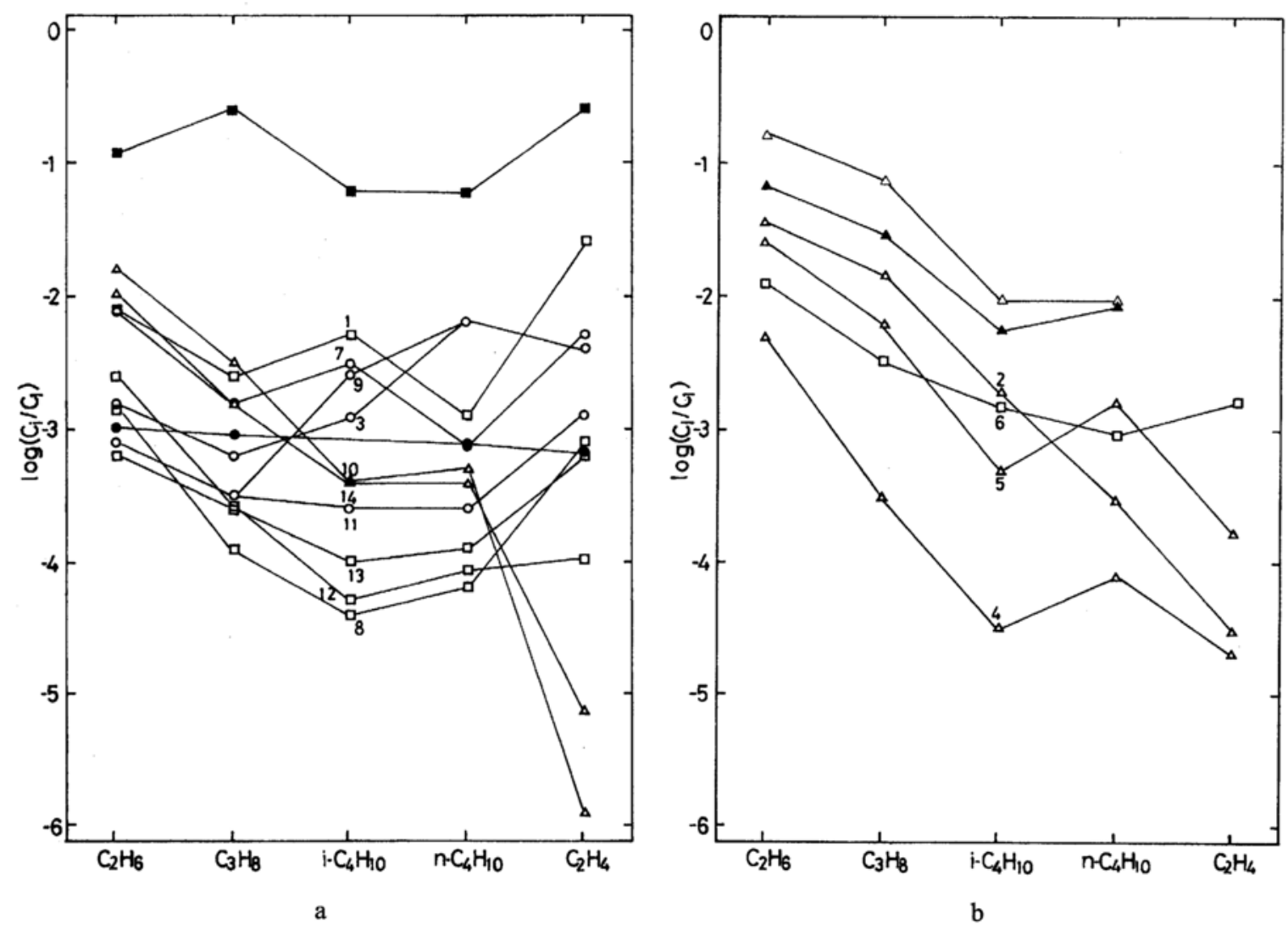

Fig. 3. Alkane and alkene concentrations relative to methane in fumarolic gases (a) and geothermal gases (b). Square, circle and triangle indicate $\mathrm{H}_{2}, \mathrm{~N}_{2}$ and $\mathrm{CH}_{4}$ type, respectively. The symbol - represents E.P.R. geothermal gases (Welhan and Craig, 1982), the Tolbachik subaerial basaltic gases (Markhim et al., 1977), $\triangle$ coal pyrolysis gases (Chung, 1976) and $\mathbf{\Delta}$ thermogenic gases (Sakata et al., 1989). The numbers are referred to the sample location shown in the caption of Fig. 2.

origin. In order to identify the contribution of different sources, we use a triangular diagram of alkanes $\left(\mathrm{CH}_{4}, \mathrm{C}_{2} \mathrm{H}_{6}\right.$ and $\left.\mathrm{C}_{3} \mathrm{H}_{8}\right)$, as shown in Fig. 4.

In a comparison of relative $\mathrm{CH}_{4}, \mathrm{C}_{2} \mathrm{H}_{6}$ and $\mathrm{C}_{3} \mathrm{H}_{8}$ contents, the first end-member to be defined is of biogenic origin (B). The biogenic pole is easily distinguishable from the magmatic pole and thermogenic domain (T). As described later, the magmatic hydrocarbons are buffered by either the fayalite-magnetite-quartz butter (FMQ) $\left(\mathrm{M}_{1}\right)$ or the magnetite-wüstite butter (MW) $\left(\mathrm{M}_{2}\right)$, and plot near the $\mathrm{CH}_{4}$ and $\mathrm{C}_{3} \mathrm{H}_{8}$ poles, respectively. The domains of submarine (Welhan and Craig, 1988; Roger et al., 1981; Welhan and Lupton, 1987) and subaerial (Markhim et al., 1977) basaltic gases are also represented in Fig. 4. Most of the data from these areas can be reasonably attributed to mixing between magmatic and thermogenic hydrocarbons. Furthermore, the magmatic end-members of both basaltic gases are FMQ $\left(\mathrm{M}_{1}\right)$ and $\mathrm{MW}\left(\mathrm{M}_{2}\right)$ buffer types. On the other hand, the samples from andestic and dacitic gases in Japan are consistent with the domain of submarine basalt. The hydrocarbons from the $\mathrm{H}_{2}$ and $\mathrm{N}_{2}$ type fumarolic gases show near magmatic values $\left(\mathrm{M}_{1}\right)$, whereas most of the $\mathrm{CH}_{4}$ type volcanic and geothermal gases contain the thermogenic compound. Therefore, fumarolic $\left(\mathrm{H}_{2}\right.$ and $\mathrm{N}_{2}$ type $)$ and geothermal $\left(\mathrm{CH}_{4}\right.$ type) hydrocarbon gases from the Japanese islands 


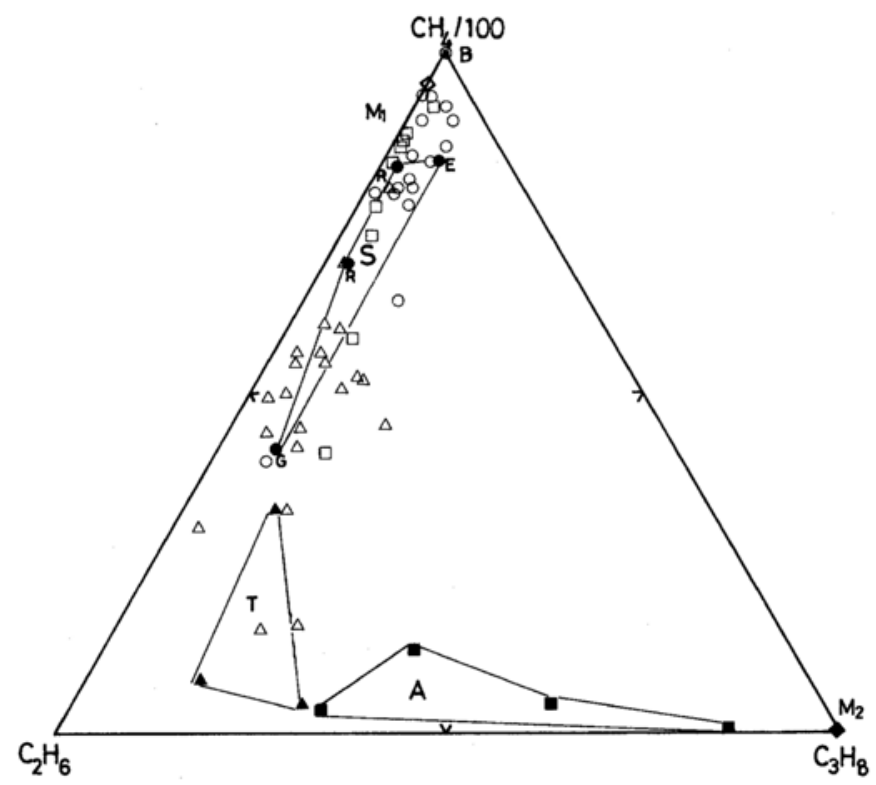

Fig. 4. $\mathrm{CH}_{4}-\mathrm{C}_{2} \mathrm{H}_{6}-\mathrm{C}_{3} \mathrm{H}_{8}$ triangular diagram. Symbols are the same as in Figs. $3 a$ and $b$. The biogenic pole (B) coincides with the $\mathrm{CH}_{4}$ pole. The magmatic hydrocarbons $\left(M_{1}\right.$ and $\left.M_{2}\right)$ have been estimated in the text. The submarine basaltic gases (S) are from Welhan and Craig (1982), Roger et al. (1981) and, Welhan and Lupton (1987). The subaerial basaltic gases (A) are from Markhim et al. (1977). The thermogenic gases (T) are from Chung (1976) and Sakata et al. (1989). E: E.P.R. (Welhan and Craig, 1982), R: Red Sea (Roger et al., 1981), G: Guaymas (Welhan and Lupton, 1987).

are likely to be largely of inorganic and thermogenic origin, respectively.

Factors controlling the abundance of inorganic hydrocarbons in volcanic gases

The possible reactions of inorganic formation of hydrocarbons in magma have been thought to be Fisher/Tropsch reactions (Craig, 1953). We would then have the following series of reactions:

$$
\begin{aligned}
& n \mathrm{CO}+(2 n+1) \mathrm{H}_{2}=\mathrm{C}_{n} \mathrm{H}_{2 n+2}+n \mathrm{H}_{2} \mathrm{O} \\
& n \mathrm{CO}+2 n \mathrm{H}_{2}=\mathrm{C}_{n} \mathrm{H}_{2 n}+n \mathrm{H}_{2} \mathrm{O} \\
& \mathrm{CO}_{2}=\mathrm{CO}+\frac{1}{2} \mathrm{O}_{2} \\
& \mathrm{H}_{2} \mathrm{O}=\mathrm{H}_{2}+\frac{1}{2} \mathrm{O}_{2}
\end{aligned}
$$

where $\mathrm{C}_{n} \mathrm{H}_{2 n+2}$ and $\mathrm{C}_{n} \mathrm{H}_{2 n}$ indicate alkanes and alkenes, respectively.

From Eqs. (1), (3) and (4) the following can be obtained

$n \mathrm{CO}_{2}+(n+1) \mathrm{H}_{2} \mathrm{O}=\mathrm{C}_{n} \mathrm{H}_{2 n+2}+\frac{(3 n+1)}{2} \mathrm{O}_{2}$.

The equilibrium constant $\mathrm{K}_{n}$ of reaction (5) is

$$
\mathrm{K}_{n}=f_{\mathrm{C}_{n} \mathrm{H}_{2 n+2}} f_{\mathrm{O}_{2}}^{(3 n+1) / 2} / f_{\mathrm{CO}_{2}}^{n} f_{\mathrm{H}_{2} \mathrm{O}}^{n+1},
$$

where $n=1,2,3, \cdots$.

Then $n=1$ :

$$
\mathrm{K}_{1}=f_{\mathrm{CH}_{4}} f_{\mathrm{O}_{2}}^{2} / f_{\mathrm{CO}_{2}} f_{\mathrm{H}_{2} \mathrm{O}}^{2} .
$$

From Eqs. (6) and (7), it can be determined that 
$f_{\mathrm{C}_{n} \mathrm{H}_{2 n+2}} / f_{\mathrm{CH}_{4}}=\left(\mathrm{K}_{n} / \mathrm{K}_{1}\right) f_{\mathrm{CO}_{2}}^{n-1} f_{\mathrm{H}_{2} \mathrm{O}}^{n-1} f_{\mathrm{O}_{2}}^{3 / 2(1-n)}$,

where $n>1$.

Similarly, the formation of ethylene can be written as

$$
2 \mathrm{CO}_{2}+2 \mathrm{H}_{2} \mathrm{O}=\mathrm{C}_{2} \mathrm{H}_{4}+3 \mathrm{O}_{2} \text {. }
$$

The equilibrium constant $\mathrm{K}_{2}^{\prime}$ of Eq. (9) is:

$$
\mathrm{K}_{2}{ }^{\prime}=f_{\mathrm{C}_{2} \mathrm{H}_{4}} f_{\mathrm{O}_{2}}^{3} / f_{\mathrm{CO}_{2}}^{2} f_{\mathrm{H}_{2} \mathrm{O}}^{2} .
$$

From Eqs. (7) and (10), it can be obtained that

$$
f_{\mathrm{C}_{2} \mathrm{H}_{4}} / f_{\mathrm{CH}_{4}}=\left(\mathrm{K}_{2}^{\prime} / \mathrm{K}_{1}\right) f_{\mathrm{CO}_{2}} f_{\mathrm{O}_{2}}
$$

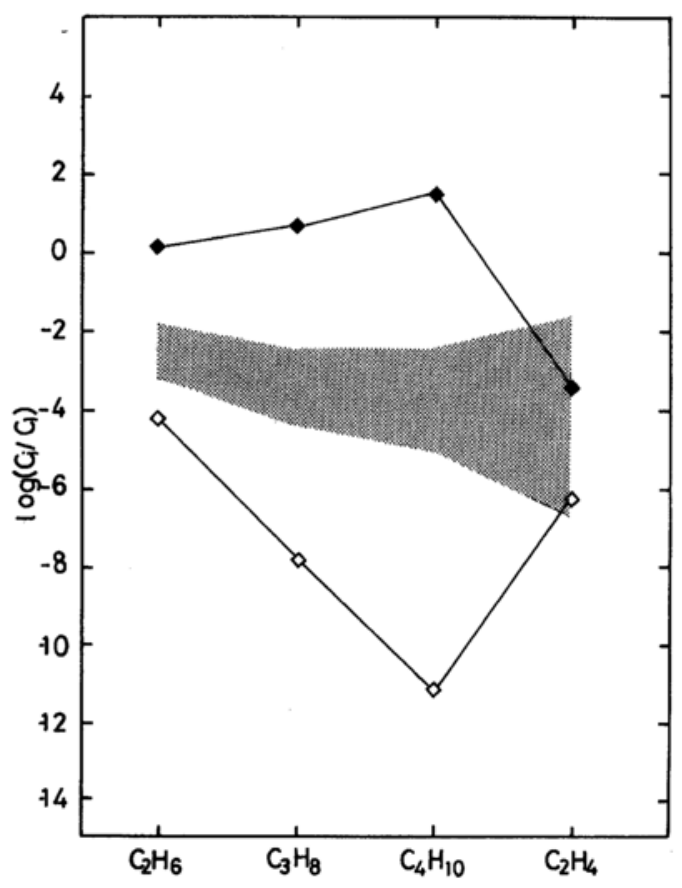

Fig. 5. Comparison of hydrocarbon concentrations relative to methane. Thermodynamic data are from Barin (1989). Temperature $=1000 \mathrm{~K}, f_{\mathrm{H}_{2} \mathrm{O}}=2 \mathrm{~kb}$, and $f_{\mathrm{CO}_{2}}=1 \mathrm{~kb}$. $\diamond$ denotes the $\mathrm{FMQ}$ (fayalite-magnetitequartz) buffer system, and $\bullet$ the $M W$ (magnetitewüstite) buffer system. The shadowed area is the observed values of fumarolic gases.
The alkane and ethylene concentrations relative to methane can then be expressed as a function of temperature, $f_{\mathrm{H}_{2} \mathrm{O}}, f_{\mathrm{CO}_{2}}$ and $f_{\mathrm{O}_{2}}$.

The concentration of $\mathrm{CO}_{2}$ in magmatic systems may also be defined by carbonate minerals as follows:

$$
\mathrm{CaCO}_{3}+\mathrm{SiO}_{2}=\mathrm{CaSiO}_{3}+\mathrm{CO}_{2}
$$

and

$$
\mathrm{FeCO}_{3}+\mathrm{SiO}_{2}=\mathrm{FeSiO}_{3}+\mathrm{CO}_{2}
$$

The lower and upper limits of $f_{\mathrm{CO}_{2}}$ can then be obtained from Eqs. (12) and (13), respectively. Therefore, the alkane and alkene concentrations relative to methane can be expressed as a function of temperature, $f_{\mathrm{H}_{2} \mathrm{O}}$ and $f_{\mathrm{O}_{2}}$.

If the oxygen fugacity of volcanic gases is controlled by the FMQ buffer at $1000^{\circ} \mathrm{K}$ and

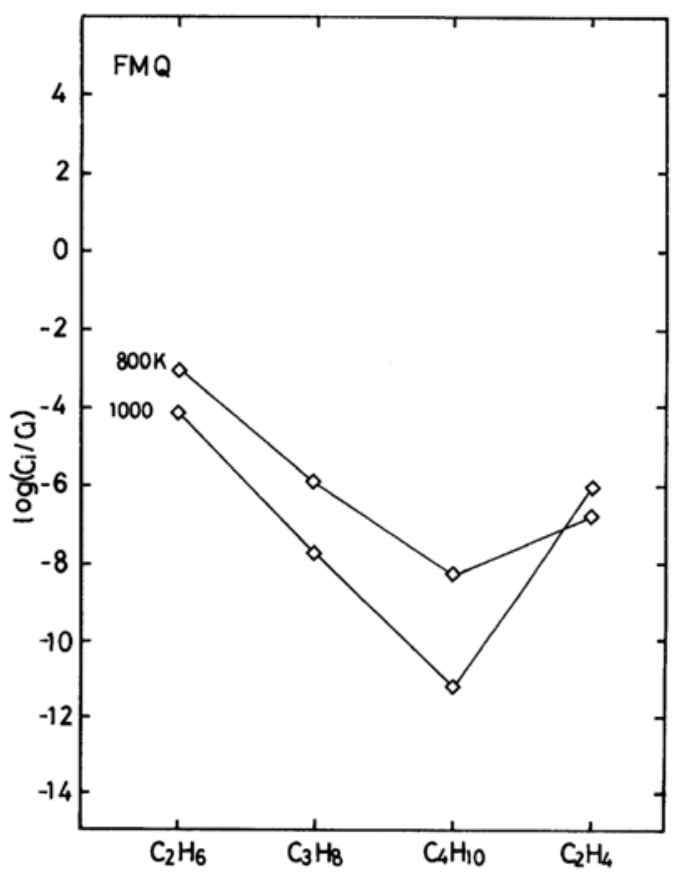

Fig. 6. Temperature effect to magmatic hydrocarbon contents relative to $\mathrm{CH}_{4}\left(C_{i} / C_{1}\right)$ when $f_{\mathrm{H}_{2} \mathrm{O}}=2 \mathrm{~kb}$, $f_{\mathrm{CO}_{2}}=1 \mathrm{~kb}(1000 \mathrm{~K})$ and $f_{\mathrm{H}_{2} \mathrm{O}}=1 \mathrm{~kb}, f_{\mathrm{CO}_{2}}=0.5 \mathrm{~kb}$ $(800 \mathrm{~K})$. 
$f_{\mathrm{H}_{2} \mathrm{O}}=2 \mathrm{~kb}$, the hydrocarbon content decreases drastically from ethane to butane, as shown in Fig. 5. Alternatively, if $f_{\mathrm{O}_{2}}$ is defined by the $\mathrm{MW}$ buffer, the alkane concentrations increase from $\mathrm{C}_{2}$ to $\mathrm{C}_{4}$. That is, the abundance pattern of the hydrocarbon appears to be largely governed by the mineral buffer systems. Therefore, under more oxidizing conditions, saturated hydrocarbons relative to methane decrease from ethane to butane, whereas under reducing condition they increase. A flat pattern with hydrocarbon contents relative to methane nearly constant, corresponds to a position between FMQ and MW oxygen buffer systems.

The effect of temperature was examined by assuming that the oxygen fugacity is controlled by the FMQ buffer (Fig. 6). Although the hydrocarbon contents relative to $\mathrm{CH}_{4}$ decrease with increasing temperature, the abundance pattern of hydrocarbons varies only slightly. On the other hand, the relationship between the abundance pat-

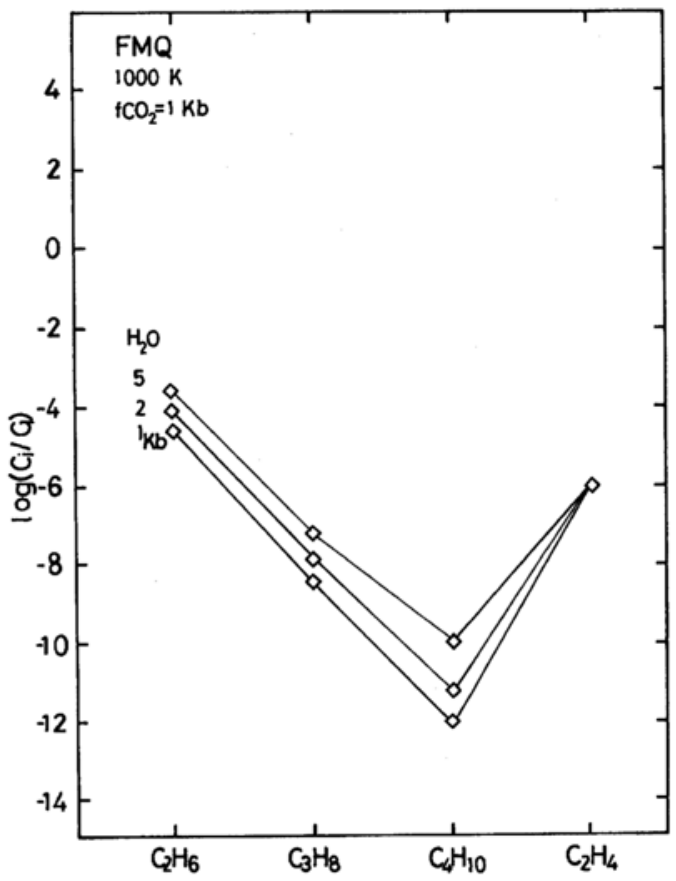

Fig. 7. Effect of water vapor fugacity to magmatic light hydrocarbon concentrations relative to methane $\left(C_{i} / C_{1}\right)$. Temp. $=1000 \mathrm{~K}, f_{\mathrm{CO}_{2}}=1 \mathrm{~kb}$. tern and water vapor is shown in Fig. 7. The alkane and ethylene concentrations relative to methane increase with increasing $f_{\mathrm{H}_{2} \mathrm{O}}$, but the pattern does not exhibit very much change.

Thus, the relative contents of light hydrocarbons are predominantly controlled by the oxygen fugacity. Most of the inorganic hydrocarbons found in volcanic gases may be formed at redox potentials between those of the FMQ and MW buffer systems are relatively independent of temperatures and $f_{\mathrm{H}_{2} \mathrm{O}}$.

\section{Magmatic hydrocarbons}

Magmatic hydrocarbons are probably controlled by the oxygen fugacity defined by the FMQ (oxidized type) or MW (reduced type) buffer. The redox potential of basaltic magmas which exist in upper mantle is close to the oxidation states of fayalite-magnetite-quartz (Haggerty, 1978; Ballhaus et al., 1990). However, electrochemical measurements suggest that the redox conditions of the upper mantle are heterogeneous, and may approach the oxygen fugacity defined by the MW buffer (Arculus, 1985; Arculus et al., 1984).

Figure 8 shows the oxygen fugacity for volcanic rocks estimated from Eq. (3). The oxygen fugacity of volcanic gases in basalt (Gerlach, 1979, $1980 \mathrm{a}, 1980 \mathrm{~b}, 1980 \mathrm{c}, 1981$ ) is consistent with that of the FMQ buffer, while those in dacite and andesite (Matsuo, 1961; Matsuo et al., 1982; Giggenbach, 1982; Guern et al., 1982) are higher than the $f_{\mathrm{O}_{2}}$ of the FMQ buffer estimated from oxide minerals (Ueda and Itaya, 1982) and near the NNO (nickel-nickel oxide) buffer. This suggests that the volcanic gases in dacite and andesite magma are significantly oxidized in the process of being discharged (Ueda and Itaya, 1982).

The isotope compositions of waters from fumarolic gases suggest that most of volcanic gases in Japan are mixtures of magmatic gases and meteoric waters (Mizutani, 1978; Kiyosu, 1983). This fact is supported by fumarolic and hot spring activities at dacitic and andesitic volcanoes in the Japanese island arc. That is, the vapour and liquid phases separate after mixing and produce fumarolic gases and volcanic acid hot springs, re- 


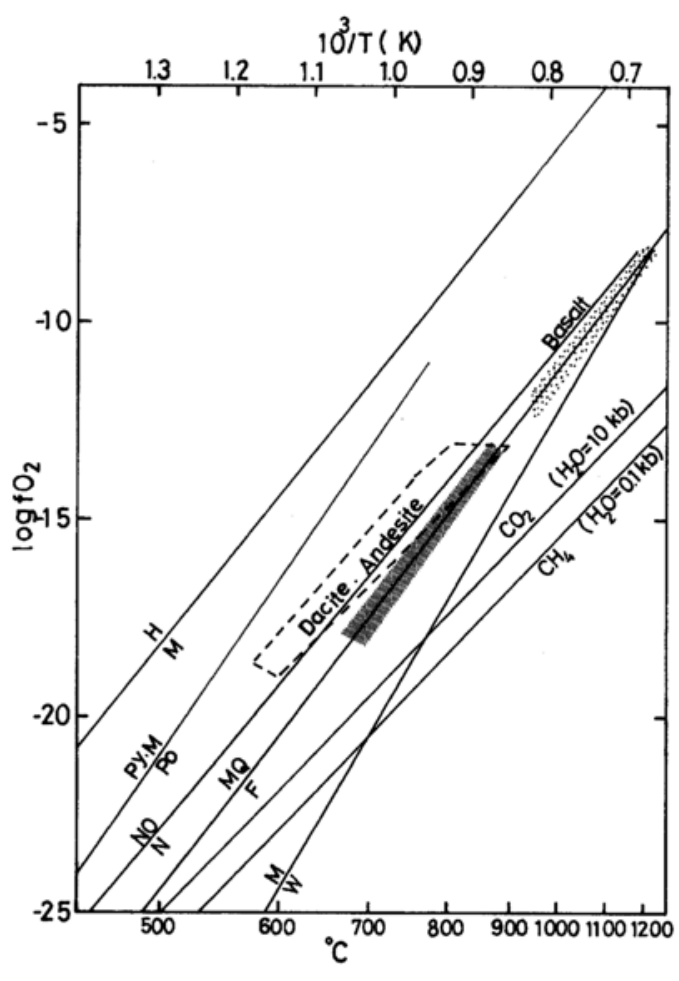

Fig. 8. Comparison of oxygen fugacities for volcanic gases. Basalt: Surtsey (Gerlach, 1980c); Mount'Etna (Gerlach, 1979); Kilauea (Gerlach, 1980a); Nyiragong (Gerlach, 1980b); Erta'Ale (Gerlach, 1981). Dacite and andesite: White Island (Giggerlbach, 1982); Ngauruhoe (Giggenbach, 1982); Merapi (LeGuern et al., 1982); Usu (Matsuo et al., 1982); Showashinzan (Matsuo, 1961); Satsuma Iwojima (Matsuo et al., 1975). Abbreviations: $H=$ hematite; $M=$ magnetite; $P y=$ pyrite; $P o=$ pyrrhotite $Q=$ quartz; $F=$ fayalite,$W=$ wüstite; $N=$ nickel; $N O=$ nickel oxide. Hatched area is the oxygen fugacity estimated from the abundance ratios of hydrocarbons in volcanic gases of $\mathrm{H}_{2}$ and $\mathrm{N}_{2}$, types at Temp. $=1000 \sim 1200 \mathrm{~K} ; f_{\mathrm{H}_{2} \mathrm{O}}=2 \mathrm{~kb} ; f_{\mathrm{CO}_{2}}=1 \mathrm{~kb}$.

spectively (Kiyosu, 1985). When oxidation and cooling of magmatic gases occur during mixing with meteoric waters, $\mathrm{CO}$ is presumably more easily oxidized by $\mathrm{H}_{2} \mathrm{O}$ than hydrocarbons. In general, the oxidation rate of hydrocarbons is slow, even at temperatures $>500^{\circ} \mathrm{C}$ (Kiyosu and Krouse, 1989).

Another possible explanation is that volcanic gases from the Japanese island arc are formed by addition of $\mathrm{CO}_{2}$ derived from the thermal decomposition of limestone or organic matter in sedimentary rocks (Marty et al., 1989). Therefore, the abundance pattern of light hydrocarbon relative to $\mathrm{CH}_{4}$ may be similar to that of the thermogenic type. However, the hydrocarbon patterns of fumarolic gases $\left(\mathrm{H}_{2}\right.$ and $\mathrm{N}_{2}$ types) found at island arc volcanoes are of the flat types as described before.

Thus, the inconsistency of the oxygen fugacity defined by FMQ buffer and the observed values in dacitic and andesitic volcanoes estimated from the $\mathrm{CO}_{2}$-CO system may be due to oxidation of volcanic gases during mixing with surface waters. The abundance ratios of light hydrocarbons which migrate to vapour phase probably do not change, since the solubility of light hydrocarbons in water is small and similar to each other (Wilhem et al., 1977). Therefore, the redox potential suggested from the abundance ratio of volcanic hydrocarbons is close to that of the FMQ buffer, as shown in Fig. 8. That is, it may be concluded that the abundance patterns of hydrocarbons found in volcanic gases directly reflect the oxidation state of magmatic gases at depth.

In general the oxygen fugacities of silicic magmas estimated from iron-titanium oxides correspond to the $\mathrm{Ni}-\mathrm{NiO}$ buffer and are higher than those of basic magmas (e.g., Carmichael, 1991). However, according to the oxygen isotope study of silicic volcanic rocks (Hildreth et al., 1984), it would appear that their magmas reacted with meteoric water. That is, silicic magmas with small amounts of iron and large amounts of water do not reflect original redox states. Accordingly the oxygen fugacities obtained from the abundance ratio of volcanic hydrocarbons in the Japanese island arc may indicate the redox states of lower crust or upper mantle suggesting deeper zones of the magma chambers. An alterative explanation could be that their relative oxygen fugacity, with respect to the FMQ, may be controlled by assimilation of reduced carbon or graphite derived from shallow crust in an ascending silicic magmas. The problem of redox states in silicic magmas require more detailed discussion in future. 
Acknowledgments-We wish to express our grateful thanks to Y. Mizutani for providing Showashinzan gas samples and for his assistance in the collection of gas samples, and $\mathrm{O}$. Matsubaya and $\mathrm{H}$. Shinohara for comments on an early version of this manuscript. We also thank two anonymous reviewers for helpful comments and suggestions on the manuscript.

\section{REFERENCES}

Arculus, R. J. (1985) Oxidation states of the mantle, past and present. Ann. Rev. Earth Planet. Sci. 13, 7595.

Arculus, R. J., Dawson, J. B., Mitchell, R. H., Gust, D. A. and Holmes, R. D. (1984) Oxidation states of the upper mantle recorded by megacryst ilmenite in kimberlite and type A and B spinel Iherzolites. Contrib. Mineral. Petrol. 85, 85-94.

Asada, N. (1991) Light hydrocarbon in volcanic gases, Unpublished Bachelor's Thesis, Nagoya University.

Asada, N. (1993) Study on genesis of volcanic gases from the Japanese island arc by carbon compounds. Unpublished Master Thesis, Nagoya University.

Ballhaus, C., Berry, R. F. and Green, D. H. (1990) Oxygen fugacity controls in the Earth's upper mantle. Nature 348, 437-440.

Barin, I. (1989) Thermochemical Data of Pure Substances, part I, II. VCH Press, Weinheim, $1739 \mathrm{pp}$.

Carmichael, I. S. E. (1991) The redox states of basic and silicic magmas: a reflection of their source regions? Contrib. Mineral. Petrol. 106, 129-141.

Chung, M. H. (1976) Isotope fractionation during maturation of organic matter, Ph.D. Dissertation, Texas A\&M University, College station, Texas (unpublished).

Craig, H. (1953) The geochemistry of the stable carbon isotopes. Geochim. Cosmochim. Acta 45, 1033-1037.

Ellis, A. J. (1957) Chemical equilibrium in magmatic gases. Amer. J. Sci. 255, 416-431.

Gerlach, T. M. (1979) Evalution and restoration of the 1970 volcanic gas analyses from Mount Etna, Sicily. J. Volcanol. Geotherm. Res. 6, 165-178.

Gerlach, T. M. (1980a) Evolution of volcanic gas analyses from Kilauea volcano. J. Volcanol. Geotherm. Res. 7, 295-317.

Gerlach, T. M. (1980b) Chemical characteristic of the volcanic gases from Nyiragongo lava lake and the generation of $\mathrm{CH}_{4}$-rich fluid inclusions in alkaline rocks. J. Volcanol. Geotherm. Res. 8, 177-189.

Gerlach, T. M. (1980c) Evalution of volcanic gas analyses from Surtsey volcano, Iceland 1964-1967. J. Volcanol. Geotherm. Res. 8, 191-198.

Gerlach, T. M. (1981) Restoration of new volcanic gas analyses from basalts of the Afar region: Further evidence of $\mathrm{CO}_{2}$-degassing trends. J. Volcanol. Geotherm. Res. 10, 83-91.

Gerlach, T. M. and Nordlie, B. E. (1975) The C-O-H$\mathrm{S}$ gaseous system, 1. Composition limits and trends in basaltic gases. Amer. J. Sci. 275, 353-376.

Giggenbach, W. F. (1982) The chemical and isotopic composition of gas discharges from New Zealand andestic volcanoes. Bull. Volcanol. 45, 253-255.

Giggenbach, W. F., Garcia, D. N., Londono, L. A., Rodriquez, V. L., Rojas, G. N. and Galvache, V. M. L. (1990) The chemistry of fumarolic vapor and thermal-spring discharges from the Nevada del Ruiz volcanic-magmatic-hydrothermal system, Colombia. J. Volcanol. Geotherm. Res. 42, 13-39.

Haggerty, S. E. (1978) The redox state of planetary basalts. Geophys. Res. Lett. 5, 443-446.

Hildreth, W., Christiansen, R. L. and O'Neil, J. R. (1984) Catastrophic isotopic modification of rhyolitic magma at times of caldera subsidence, Yellowstone Plateau volcano field. J. Geophys. Res. 89, 83398369.

Kiyosu, Y. (1983) Hydrogen isotopic compositions of hydrogen and methane from some volcanic areas in northeastern Japan. Earth Planet. Sci. Lett. 62, 41-52.

Kiyosu, Y. (1985) Isotopic composition of acid sulfatechloride waters and volcanic steam from some volcanoes in northeastern Japan, J. Volcanol. Geotherm. Res. 26, 25-36.

Kiyosu, Y. (1986) Origin of geothermal fluid in the Onikobe area. Chikyukagaku 59-68 (in Japanese).

Kiyosu, Y. and Krouse, H. R. (1989) Carbon isotope effect during abiogenic oxidation of methane. Earth Planet. Sci. Lett. 95, 302-309.

Kiyosu, Y. and Yoshida, Y. (1988) Origin of some gases from the Takinoue geothermal area in Japan. Geochem. J. 22, 183-193.

LeGuern, F., Gerlach, T. M. and Nohl, A. (1982) Field gas chromatograph analyses of gases from a glowing dome at Merapi volcano, Java, Indonesia, 1977, 1978, 1979. J. Volcanol. Geotherm. Res. 14, 223-245.

Markhim, Y. K., Urakov, V. A. and Podkletonov, N. Y. (1977) Hydrocarbons in gases of basalt lava streams of the Tolbachik fissure eruption in 1975 and 1976. Doklady Akad. Nauk. SSSR 236, 211-214.

Marty, B., Jambon, A. and Sano, Y. (1989) Helium isotopes and $\mathrm{CO}_{2}$ in volcanic gases of Japan. Chem. Geol. 76, 25-40.

Matsuo, S. (1960) On the origin of volcanic gases. $J$. Earth Sci. Nagoya Univ. 8, 222-245.

Matsuo, S. (1961) On the chemical nature of fumarolic gases of volcano, Showashinzan, Hokkaido, Japan. J. Earth Sci. Nagoya Univ. 9, 80-100.

Matsuo, S., Ossaka, J., Hirabayashi, J., Ozawa, T. and Kimishima, K. (1982) Chemical nature of volcanic 
gases of Usu volcano in Japan. Bull. Volcanol. 45, 261-264.

Matsuo, S., Suzuoki, T., Kusakabe, M., Wada, H. and Suzuki, M. (1975) Isotopic and chemical composition of volcanic gases from Satsuma-Iwojima, Japan. Geochem. J. 8, 165-173.

Mizutani, Y. (1978) Isotopic compositions of volcanic steam from Showashinzan volcano, Hokkaido, Japan. Geochem. J. 12, 57-63.

Mizutani, Y., Hayashi, S. and Sugiura, T. (1986) Chemical and isotopic compositions of fumarolic gases from Kuju-Iwoyama, Kyushu, Japan. Geochem. J. 20, 273-285.

Nehring, N. L. and Truesdell, A. H. (1978) Hydrocarbon gases in some volcanic and geothermal systems. Geotherm. Res. Counc. Trans. 2, 483-486.

Ozawa, T. (1966) Chemical analysis of volcanic gases containing water vapor hydrogen chloride, sulfur dioxide, hydrogen sulfide, carbon dioxide, etc. J. Chem. Soc. Jpn. 87, 848-853.

Roger, A., Burke, \$., Jr., Brooks, J. M. and Sackett, W. M. (1981) Light hydrocarbons in Red Sea brines and sediments. Geochim. Cosmochim. Acta 45, 627634.

Sakata, S., Takahashi, M., Igari, S. and Suzuki, N. (1989) Origin of light hydrocarbons from volcanic rocks in The "Green tuff" region of Northeast Japan: Biogenic versus Magmatic. Chem. Geol. 74, 241-248.

Schoell, M. (1988) Multiple origin of methane in the Earth. Chem. Geol. 71, 1-10.
Stoiber, R. E., Leggett, D. C., Jenkins, T. F., Murrmann, R. P. and Rose, W. I., Jr. (1971) Organic compounds in volcanic gas from Santiaguito volcano, Guatemala. Geol. Soc. America Bull. 82, 2299-2302.

Taran, Y. A., Pokrovsky, B. G. and Dubik, Y. M. (1990) Isotope composition and origin of water in andesite magma. Doklady 304, 196-199.

Ueda, A. and Itaya, T. (1981) Microphenocrystic pyrrhotite from Dacite rocks of Satsuma-Iwojima, Southwest Kyushu, Japan and the solubility of sulfur in dacite magma. Contrib. Mineral Petrol. 78, 21-26.

Viglino, J. A., Harmon, R. S., Borthwick, J., Nehring, N. L., Motyka, R. J., White, L. D. and Johnston, D. A. (1985) Stable-isotope evidence for a magmatic component in fumarole condensates from Augustine volcano, Cookinlet, Alaska, U.S.A. Chem. Geol. 49, 141-157.

Welhan, J. A. (1988) Origins of methane in hydrothermal systems. Chem. Geol. 71, 183-198.

Welhan, J. A. and Craig, H. (1982) Abiogenic methane in mid-ocean ridge hydrothermal fluids. Deep Source Gas Workshop Tech. Proc. (Gwilliann, W. J., ed.), 122-128, Morgantown, W. Va. DOE-METC-82-50.

Welhan, J. A. and Lupton, J. E. (1987) Light hydrocarbon gases in Guaymas Basin hydrothermal fluids: Thermogenic versus Abiogenic origin. Amer. Ass. Peterol. Geol. Bull. 71, 215-223.

Wilhem, E., Battino, R. and Wilcock, R. J. (1977) Low pressure solubility of gases in liquid water. Chem. Rev. 77, 219-261. 